\title{
Implementation of an interactive mobile application to pilot a rapid assay to detect HIV drug resistance mutations in Kenya
}

Justin D. Vrana ${ }^{1 *}$, Nuttada Panpradist ${ }^{1,2^{*}}$, Nikki Higa ${ }^{3}$, Daisy $\mathrm{Ko}^{3}$, Parker Ruth ${ }^{1,4}$, Ruth

Kanthula ${ }^{1,3}$, James J. Lai ${ }^{1}$, Yaoyu Yang ${ }^{5}$, Samar R. Sakr ${ }^{6}$, Bhavna Chohan ${ }^{7,8}$, Michael H. Chung, Lisa M. Frenkel ${ }^{3,10}$, Barry R. Lutz ${ }^{1}$, Eric Klavins ${ }^{5}{ }^{\S}$, Ingrid A. Beck ${ }^{3 \S}$

1 Department of Bioengineering, University of Washington, Seattle, Washington, USA

2 Global Health of Women, Adolescents, and Children (Global WACh), School of Public Health, University of Washington, Seattle, Washington, USA

3 Center for Global Infectious Disease Research, Seattle Children's Research Institute, Seattle, Washington, USA

4 Paul G. Allen Center for Computer Science \& Engineering, University of Washington, Seattle, Washington, USA

5 Department of Electrical and Computer Engineering, University of Washington, Seattle, Washington, USA

6 Coptic Hope Center for Infectious Diseases, Nairobi, Kenya

7 Center for Virus Research, Kenya Medical Research Institute, Nairobi, Kenya

8 Department of Global Health, University of Washington, Seattle, Washington, USA

9 Department of Medicine, Emory University, Atlanta, Georgia, USA

10 Departments of Global Health, Medicine, Pediatrics, and Laboratory Medicine, University of Washington, Seattle, Washington, Washington, United States

* Authors contributed equally.

$\S$ Corresponding authors:

Eric Klavins

Biosystems, Robotics, and Controls

Department of Electrical and Computer Engineering

University of Washington

Paul Allen Center, 185 E Stevens Way NE AE100R, Seattle, WA 98195

206-221-5270

klavins@ece.uw.edu 
Ingrid A. Beck

307 Westlake Ave. N

Seattle, WA 98109, USA

206-884-3440

ingrid.beck@seattlechildrens.org

E-mail addresses of authors:

JDV: jvrana@uw.edu

NP: nuttadap@uw.edu

NH:nhiga@usc.edu

DK: Daisy.Ko@seattlechildrens.org

PR:psr23@uw.edu

RK: Ruth.M.Kanthula@gunet.georgetown.edu

JJL:jilai@uw.edu

YY:yaoyu@uw.edu

SRS: amsa737@gmail.com

BC: bchohan@uw.edu

MHC: mhchung@uw.edu

LMF: 1frenkel@uw.edu

BRL: blutz@uw.edu

Keywords: HIV drug resistance, rapid assay, implementation, mobile application, laboratory operating system, oligonucleotide ligation assay, low-resource settings

Abstract: 282 words

Main text: 2085 words 
medRxiv preprint doi: https://doi.org/10.1101/2021.05.06.21256654; this version posted May 8, 2021. The copyright holder for this preprint (which was not certified by peer review) is the author/funder, who has granted medRxiv a license to display the preprint in perpetuity. It is made available under a CC-BY-NC-ND 4.0 International license .

\section{Abstract}

3 Introduction: Usability is an overlooked aspect of implementing lab-based assays, particularly novel assays in low-resource-settings. Esoteric instructions can lead to irreproducible test results and patient harm. To address these issues, we developed a software application based on "Aquarium", a laboratory-operating system run on a computer tablet that provides step-by-step digital interactive instructions, protocol management, and sample tracking. Aquarium was paired with a near point-of-care HIV drug resistance test, "OLA-Simple", that detects mutations associated with virologic failure. In this observational study we evaluated the performance of Aquarium in guiding untrained users through the multi-step laboratory protocol with little supervision.

Methods: A feasibility study was conducted in a laboratory at Coptic Hope Center in Nairobi, Kenya. To evaluate the training by Aquarium software, twelve volunteers who were unfamiliar with the kit performed the test on blinded samples ( 2 blood specimens; 5 codons/sample). Steps guided by Aquarium included: CD4+ T-Cell separation, PCR, ligation, detection, and interpretation of test results. Participants filled out a short survey regarding their demographics

Results and discussion: 12/12 laboratory technicians had no prior experience performing CD4+ separation and 7/12 had no experience performing laboratory-based molecular assays. 12/12 isolated CD4+ T cells from whole blood with yields comparable to isolations performed by trained personnel. The OLA-Simple workflow was completed by all, with correct visual and software interpretation of results for $90 \%(108 / 120)$ and $97 \%(116 / 120)$ of codons, respectively. In the surveys, participants favorably assessed the use of software guidance.

27 Conclusions: Aquarium digital instructions enabled first-time users in Kenya to complete the 28 OLA-simple kit workflow with minimal training. Aquarium could increase the accessibility of 29 laboratory assays in low-resource-settings and potentially standardize implementation of clinical 30 laboratory tests. 
medRxiv preprint doi: https://doi.org/10.1101/2021.05.06.21256654; this version posted May 8, 2021. The copyright holder for this preprint (which was not certified by peer review) is the author/funder, who has granted medRxiv a license to display the preprint in perpetuity. It is made available under a CC-BY-NC-ND 4.0 International license .

\section{Introduction}

In resource-rich communities, automation drastically improves the daily operation of clinical laboratories [1-3]. Patient samples can be quickly shipped to centralized laboratories for batchprocessing using highly-efficient workflows that generate high-quality results while reducing costs and turnaround time [4,5]. However, total automation is ill-suited for low-resource settings for many reasons. First, shipping of samples to centralized laboratories can take $\geq 10$ days [6], which undermines the benefits of fast turnaround test results from an automated workflow. Second, in small communities, the demand of a clinical assay may be low, requiring a longer waiting period to receive enough samples to complete a full batch. Finally, automation is often used in conjunction with high-throughput robotic equipment that is cost-prohibitive for small laboratories. In lowresource settings, high-quality and fast laboratory results for complex assays will likely require unorthodox approaches to automation to build on low-cost equipment and be applicable for small batches of samples.

HIV infects nearly 40M people globally [7] and successful management of HIV relies on multiple laboratory tests. Recent advances include point-of-care HIV diagnosis and viral load quantification $[8,9]$. Due to the complexity of HIV drug resistance (HIVDR) tests used to guide treatment regimens, they are performed in centralized, highly-equipped laboratories [10-13]. In low-resource countries with high HIV prevalence like Kenya, few laboratories have the capacity to test for HIVDR [14]. For laboratories without access to sequencers, an oligonucleotide ligation assay (OLA) has been implemented [15] but onboarding OLA required extensive training due to its complexity.

We envision the use of software to automate a simplified version of OLA that uses low-cost equipment. To that end, we developed "OLA-Simple" which uses lyophilized reagents to simplify the workflow and lateral flow tests to provide visual results [16-18]. In addition, we developed a software application based on "Aquarium" [19] that employs human-in-the-loop automation to

61 tightly integrate all the steps in OLA-Simple. Aquarium provides step-by-step interactive digital 62 instructions, protocol management, data collection and sample tracking. In a pilot study at the 
medRxiv preprint doi: https://doi.org/10.1101/2021.05.06.21256654; this version posted May 8, 2021. The copyright holder for this preprint (which was not certified by peer review) is the author/funder, who has granted medRxiv a license to display the preprint in perpetuity. It is made available under a CC-BY-NC-ND 4.0 International license .

the OLA-Simple workflow [18]. Here, we demonstrate the use of the Aquarium-enabled HIVDR test in a small laboratory in Nairobi, Kenya.

Methods

A Seattle team travelled to Nairobi in April 2018 to set-up a testing site at the Coptic Hope Center for Infectious Diseases, which is a large-scale, antiretroviral treatment site [20]. The laboratory's existing standard thermal cycler, biological safety hood, bench space, and refrigerator were utilised. To onboard the test, the team brought the OLA-Simple kits, minicentrifuge, micropipettes, scanner (CanoScan LiDE 300), and tablets (Fire HD), foot pedal, UPS battery backup and surge protector (APC 1500VA Compact), and server (Intel NuC NUC7i3BNH Mini PC/HTPC) to set up and run Aquarium. Aquarium code is publicly available [21].

\section{Study design}

This feasibility study was designed to evaluate the utility and performance of Aquarium in guiding first-time users to perform the OLA-Simple kits. We recruited 12 laboratory technicians from the Coptic Hospital clinical laboratories to perform OLA-simple following the instructions provided by the Aquarium-based application from April 4 - 13, 2018. Considering the timeframe and resources, we estimated this sample size was adequate to assess the test performance and obtain feedback on the participants' perceptions related to the OLA-Simple kit and Aquarium digital instructions. This study was approved by the Institutional Ethics Review Committee (IERC) of the Aga Khan University in Kenya and Seattle Children's Research Institute's IRB.

\section{Evaluation of OLA-Simple by participating laboratory technicians}

89 Testing was spread over six days (two techs/day) and consisted of completing a demographic

90 questionnaire and a 30-minute introduction of the kit principle and procedure, followed by

91 processing and testing of two blinded blood samples. CD4+ cells were separated from $0.5 \mathrm{~mL}$

92 uninfected blood and lysed. The cell lysates were then spiked with mixtures of plasmids

93 containing known HIV drug resistance mutations and amplified by PCR, followed by ligation of

94 mutation-specific probes and detection of the ligated products using lateral flow strips. The 
medRxiv preprint doi: https://doi.org/10.1101/2021.05.06.21256654; this version posted May 8, 2021. The copyright holder for this preprint (which was not certified by peer review) is the author/funder, who has granted medRxiv a license to display the preprint in perpetuity. It is made available under a CC-BY-NC-ND 4.0 International license .

lateral flow strips were scanned, and the images displayed on the tablets were used by the participants to make visual calls and generate a report using Aquarium. Finally, the participants completed a questionnaire to give feedback on their experience with the kits and software.

\section{Preparation of OLA-Simple kits}

The OLA-Simple kit was prepared and assembled as previously described [22]. The EasySep isolation kit (STEMCELL Technologies, Vancouver, CA) to negatively select CD4+ T-Cells was adapted to small blood volume processing, aliquoted and packaged in foil pouches. Reagents for PCR, ligation for detection of five HIV major NNRTI/NRTI resistance codons (K65R, K103N, Y181C, M184, and G190A) and lateral flow strips to detect ligation products were packaged in foil pouches with desiccant. Each kit component was labeled with a unique identifier, matching the images illustrated in Aquarium instructions.

\section{Post-analysis of samples in Seattle.}

The DNA yield in lysed cells obtained by Kenyan participants was assessed in Seattle by qPCR of human beta globin [23]. The lateral flow images and Aquarium reports generated by each participant were used to assess assay performance and interpretation of visual results. Test accuracy was determined by comparison to the expected genotype at each codon analysed. Scanned images of lateral flow strips were re-analysed using an in-house Python script [22] to determine if automated analyses improved test accuracy. 95\% confidence intervals (CI) are reported for all proportions.

\section{Participant characteristics}


126 The 12 participants recruited were $83 \%$ male, median age 30 years old (range 26-42), had a

127 median of 6 (range 3-10) years of experience as a laboratory technician, and all were conversant

128 in English. Their education level ranged from secondary school with a certificate in Medical

129 Laboratory Technology to a Master's degree in a Laboratory Science field, which is

130 representative of most clinical laboratories in Kenya. They reported varied levels of experience

131 working with HIV or molecular techniques (Table 1).

133 Table 1. Demographics of participants $(\mathbf{N}=12)$

134

\begin{tabular}{|c|c|}
\hline Variable & Number \\
\hline Age, median (range), years & $30(26-42)$ \\
\hline \multicolumn{2}{|l|}{ Gender, N (\%) } \\
\hline Male & $10(83.3)$ \\
\hline Female & $2(16.7)$ \\
\hline \multicolumn{2}{|l|}{ Primary language, $\mathrm{N}(\%)$} \\
\hline English & $4(33.3)$ \\
\hline Swahili & $1(8.3)$ \\
\hline English and Swahili & $7(58.3)$ \\
\hline \multicolumn{2}{|l|}{ Highest education level, N (\%) } \\
\hline Masters & $1(8.3)$ \\
\hline Bachelor & $3(25)$ \\
\hline Technical/Vocational training & $2(16.7)$ \\
\hline Secondary school diploma & $6(50)$ \\
\hline $\begin{array}{l}\text { Years of experience as a lab technologist/technician, median } \\
\text { (range) }\end{array}$ & $6(3-10)$ \\
\hline Hours/week worked for pay in current position, median (range) & $45(40-54)$ \\
\hline \multicolumn{2}{|l|}{ Current position in laboratory, $\mathrm{N}$} \\
\hline Laboratory manager & 2 \\
\hline Lab technologist $\dagger$ & 4 \\
\hline Lab technician $\dagger$ & 6 \\
\hline Ever performed lab procedures related to HIV, N (\%) & $10(83.3)$ \\
\hline Viral load tests & 2 \\
\hline CD4 testing & 3 \\
\hline ELISA test & 2 \\
\hline Phlebotomy and blood separation & 5 \\
\hline Ever performed DNA or RNA extraction, N (\%) & $5(41.7)$ \\
\hline $\begin{array}{l}\text { Kit (Qiagen, COBAS Ampliprep and Taqman, Abbott } \\
\text { M2000rt }\end{array}$ & 3 \\
\hline Sputum lysis for Genexpert & 1 \\
\hline Cavidi technology & 1 \\
\hline
\end{tabular}


$\dagger$ Participants performed tests in one or several of the following areas: microbiology, hematology, biochemistry, parasitology, immunology sections, CD4/8, Genexpert (TB), ELISA

\section{Laboratory setup for Aquarium-assisted OLA-Simple training}

140 The installation cost of OLA-Simple is low compared to automated sequencing platforms (> US\$

141 100,000). The workflow uses equipment that exists in most laboratories or is relatively

142 inexpensive to acquire. Setting up the assay and software at the Coptic Hope Center laboratory

143 required $\sim$ US $\$ 1,000$ of additional equipment (scanner, microcentrifuge, vortexer, computer

144 tablets, a server, and an uninterruptible power supply). For a laboratory without access to a

145 thermal cycler, a battery-powered portable unit $(\sim 500)$ can be used as we have previously

146 shown [24].

148 The laboratory was set up with a Wi-Fi network to run Aquarium and coordinate assay steps 149 across a pre-PCR and post-PCR room (Figure 1A). Participants worked in pairs following the 150 implementation workflow (Figure 1B): sample preparation and PCR set-up were carried out in 151 the pre-PCR room, while PCR, ligation and detection were conducted in the post-PCR room to 152 minimise potential for amplicon-carryover contamination. Each participant processed two 153 uninfected blood specimens and performed mutation testing on two contrived specimens with 154 known HIV mutations following the interactive digital instructions provided by Aquarium. 
medRxiv preprint doi: https://doi.org/10.1101/2021.05.06.21256654; this version posted May 8, 2021. The copyright holder for this preprint (which was not certified by peer review) is the author/funder, who has granted medRxiv a license to display the preprint in perpetuity.

It is made available under a CC-BY-NC-ND 4.0 International license .

\section{A}

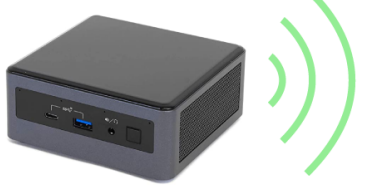

Local server connected to tablets running Aquarium software to guide users through steps, track samples, and record results

\section{Pre-PCR room}

(Photo of a technician read the instructions on the Aquarium tablet and processed samples)

Removed to meet MedRXiv policy. Available upon request.

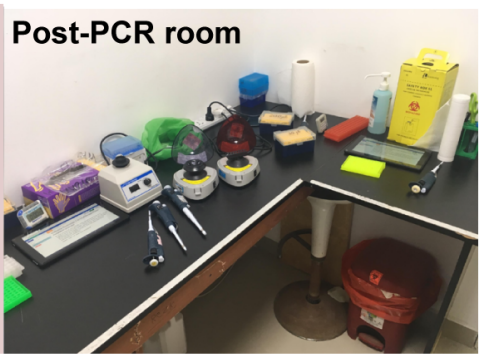

B

Performed by Seattle team in Kenya

Performed by enrolled technicians in Kenya

Performed by Seattle team in Seattle

\section{qPCR to quantify \\ DNA yield in \\ cell lysates}

\section{"Laboratory Manager"}

assigns tasks on

Figure 1. OLA-Simple laboratory setup and workflow. (A) Laboratory setup: Tablets were

connected to a local server to run Aquarium software. The pre-PCR room had a

refrigerator/freezer and a BSC where CD4+ separation and PCR reaction were set-up.

Technicians controlled the Aquarium-based software on the tablet with a foot pedal (not shown in the picture) while performing CD4+ preparation. The post-PCR room had two designated bench areas to set up ligation and detection separately. This room also contained a thermal cycler and a scanner. (B) Tasks assigned by Aquarium for Kenyan technicians to perform, and assessment of their performance using Aquarium-assisted OLA-Simple. The sample preparation module was separated from the amplification, ligation, detection, and interpretation module. 
medRxiv preprint doi: https://doi.org/10.1101/2021.05.06.21256654; this version posted May 8, 2021. The copyright holder for this preprint (which was not certified by peer review) is the author/funder, who has granted medRxiv a license to display the preprint in perpetuity. It is made available under a CC-BY-NC-ND 4.0 International license .

On average, it took seven hours for a pair of participants to complete the tasks in the workflow from introductory session to completion of surveys. This turnaround time also included staggering the work of two participants due to space and instrument constraints and would likely decrease to 4.5-5 hours once users became familiar with the software and the kits.

Reported turnaround time for centralised HIVDR testing in resource-limited settings is 18 days [25] from sample collection, shipping to the laboratory, processing of samples, and transmission of results to the clinic. In this study, OLA-Simple was performed in a laboratory located within the hospital grounds and thus could deliver test results within one day. In addition, each kit tests two samples, a number suitable for the volume of weekly patient samples submitted for HIVDR testing in small laboratories in Kenya, which eliminates the need to batch specimens for testing.

\section{Performance of participants using OLA-Simple}

All 12 participants successfully isolated CD4+ cells from whole blood collected from four donors with yields within the expected range (mean \pm SD: $686,450 \pm 216,500 \mathrm{CD} 4+$ cells/mL, as determined by qPCR) and completed genotyping of two samples using the OLA-Simple kit reagents and protocols as instructed by the Aquarium application. The two blinded DNA samples tested by all participants included wild-type genotype only or mixtures of mutant and wild-type genotypes at each of five HIV reverse transcriptase codons tested by OLA-Simple: K65R, K103N, Y181C, M184V and G190A (total of 10 codons/participant) (Figure 2A). Participants correctly genotyped 70/72 (97.2\%, 95\% CI: 90-100\%) mutant codons and 38/48 (79.2\%, 95\% CI: $65-90 \%)$ wild-type codons. The only two false negatives were due to Participant \#6 erroneously testing Sample 1 twice and omitting testing of Sample 2. Of 10 false positive results,

1912 were due to testing Sample 1 in place of Sample 2 by Participant \#6, 1 appeared to be 192 contamination (light mutant signal at codon G190A likely from reusing a pipette tip 193 contaminated with mutant ligation product) and 7 were due to light mutant background at codons $194 \mathrm{~K} 103 \mathrm{~N}(\mathrm{n}=6)$ and K65R $(\mathrm{n}=1)$. Analysis of the scanned images using our in-house image 195 analysis software improved test accuracy to 97\% (116/120, 95\% CI: 92-99\%) with 97\% (70/72, 196 95\% CI: 90-99\%) mutant codons and 96\% (46/48 95\% CI: 86-99\%) wild-type codons correctly 197 genotyped (Figure 2B). 
medRxiv preprint doi: https://doi.org/10.1101/2021.05.06.21256654; this version posted May 8, 2021. The copyright holder for this preprint (which was not certified by peer review) is the author/funder, who has granted medRxiv a license to display the preprint in perpetuity.

It is made available under a CC-BY-NC-ND 4.0 International license .

\begin{tabular}{|c|c|c|c|c|c|c|c|c|c|c|}
\hline $\begin{array}{l}\text { Specificity: } \\
79 \% \text { visual calls } \\
96 \% \text { software }\end{array}$ & - & I & $=$ & E & - & $=$ & I & $\exists$ & - & $\begin{array}{l}\text { \&Ctrl } \\
\leftarrow \text { WT } \\
-\mathrm{MU}\end{array}$ \\
\hline $\begin{array}{l}\text { Overall } \\
\text { accuracy: } \\
90 \% \text { visual calls } \\
97 \% \text { software }\end{array}$ & s & 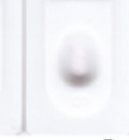 & 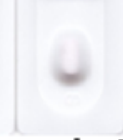 & - & 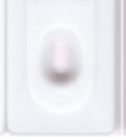 & 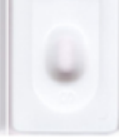 & 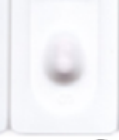 & 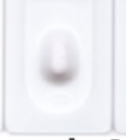 & 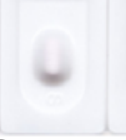 & 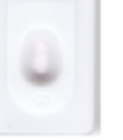 \\
\hline & \multicolumn{5}{|c|}{ Sample 1} & \multicolumn{5}{|c|}{ Sample 2} \\
\hline \multirow{2}{*}{$\begin{array}{c}\text { Expected } \\
\text { results }\end{array}$} & WT & MUT & MUT & MUT & WT & MUT & WT & MUT & WT & MUT \\
\hline & K65R & K103N & Y181C & M184V & G190A & K65R & K103N & Y181C & M184V & G190A \\
\hline \multirow{2}{*}{$\begin{array}{l}\text { Accuracy rate } \\
\text { by visual calls }\end{array}$} & $11 / 12$ & $12 / 12$ & $12 / 12$ & $12 / 12$ & $11 / 12$ & $11 / 12$ & $5 / 12$ & $12 / 12$ & $11 / 12$ & $11 / 12$ \\
\hline & $92 \%$ & $100 \%$ & $100 \%$ & $100 \%$ & $92 \%$ & $92 \%$ & $42 \%$ & $100 \%$ & $92 \%$ & $92 \%$ \\
\hline \multirow{2}{*}{$\begin{array}{c}\text { Accuracy rate } \\
\text { by software } \\
\text { analysis }\end{array}$} & $12 / 12$ & $12 / 12$ & $12 / 12$ & $12 / 12$ & $12 / 12$ & $11 / 12$ & $11 / 12$ & $12 / 12$ & 11/12 & $11 / 12$ \\
\hline & $100 \%$ & $100 \%$ & $100 \%$ & $100 \%$ & $100 \%$ & $92 \%$ & $92 \%$ & $100 \%$ & $92 \%$ & $92 \%$ \\
\hline \multirow{3}{*}{$\begin{array}{c}\text { Accuracy rate } \\
\text { by software } \\
\text { analysis } \\
\text { (corrected)* }\end{array}$} & 13/13 & $13 / 13$ & $13 / 13$ & $13 / 13$ & $13 / 13$ & $11 / 11$ & $11 / 11$ & $11 / 11$ & $11 / 11$ & $11 / 11$ \\
\hline & $100 \%$ & $100 \%$ & $100 \%$ & $100 \%$ & $100 \%$ & $100 \%$ & $100 \%$ & $100 \%$ & $100 \%$ & $100 \%$ \\
\hline & * Technic & cian 6 use & d the sam & ne sample & twice. & & & & & \\
\hline
\end{tabular}

B

Performed by Technician 6

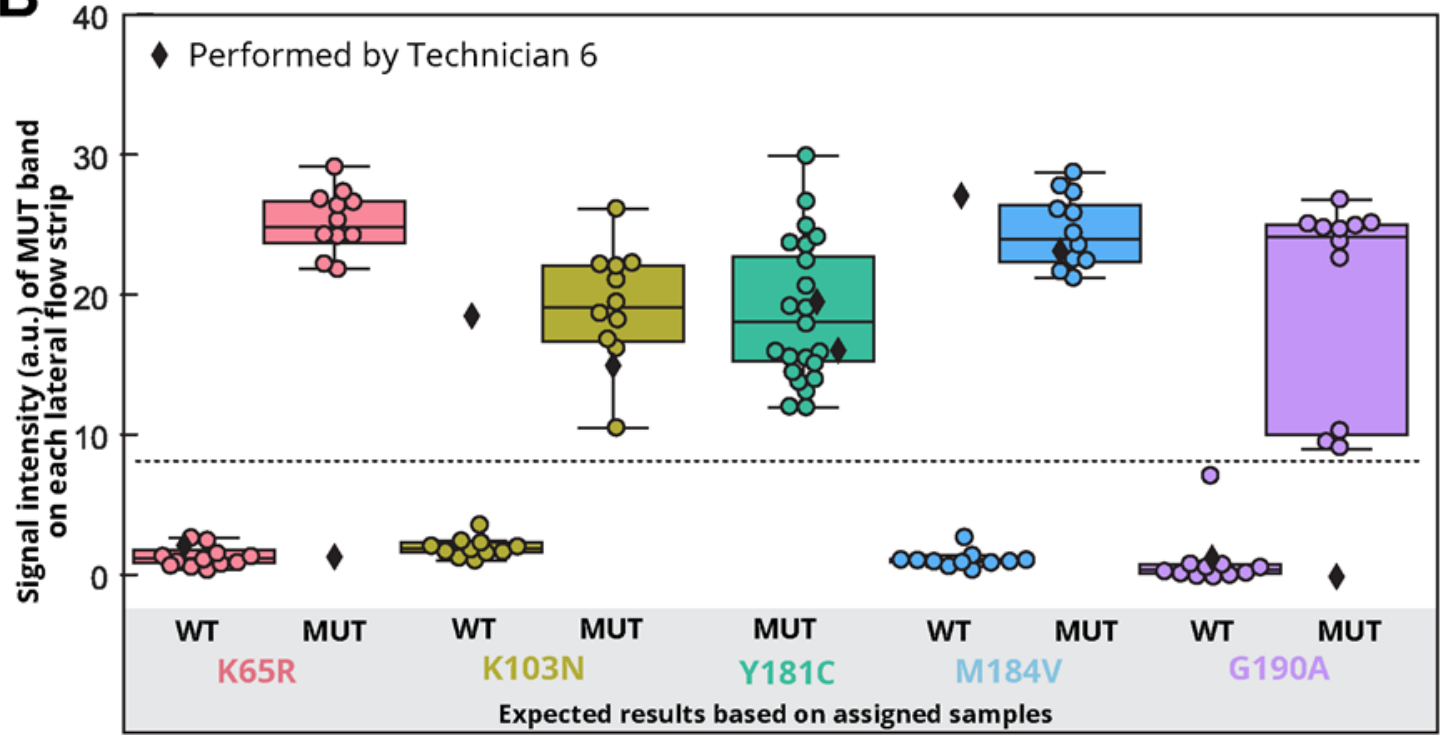

200 Figure 2. OLA-Simple HIVDR results and interpretations. (A) Examples of scanned images

201 of test strips for Samples 1 and 2 and test accuracy across each codon based on visual calls made

202 by each participant and post-processing by image analysis software. Sample1 and Sample 2 have 203 different mutation profiles. (B) Mutant (MUT) signal intensity of each lateral flow strip. Middle

204 lines on the box plot indicate medians. Top and bottom lines on box plot indicate interquartile 205 ranges. Dashed lines indicate the detection threshold for MUT signal. Both Sample 1 and Sample 
medRxiv preprint doi: https://doi.org/10.1101/2021.05.06.21256654; this version posted May 8, 2021. The copyright holder for this preprint (which was not certified by peer review) is the author/funder, who has granted medRxiv a license to display the preprint in perpetuity. It is made available under a CC-BY-NC-ND 4.0 International license .

2 have mutant genotype at codon Y181C. Diamonds correspond to signal from the strips of a Sample 1 that was erroneously tested in place of Sample 2.

The image analysis software improved accuracy over visual interpretation of results by establishing a signal threshold above the mutant background signal and thus eliminating false

211 positives. The sample mix-up described above reduced the overall accuracy; this could be 212 improved with changes in the kit labeling system to prevent this type of errors. Correcting for the 213 sample that was added twice, the performance of the assay chemistry combined with software 214 analysis, yielded 100\% accuracy (120/120, 95\% CI: 97-100\%) with correct results for 100\% 215 (72/72, 95\% CI: 95-100\%) mutant codons and 100\% (48/48 95\% CI: 93-100\%) wild-type 216 codons.

\section{Feedback on software and kit features}

219 Overall, participants scored the use of software as helpful in learning to perform the assay.

220 Qualitatively, participants enjoyed the clear instructions and interpretability of the results using

221 the tablets. They strongly agreed that they understood the meaning of the bands on the strips, and

222 that the Aquarium instructions were easy to follow. However, several participants felt the

223 procedure was lengthy and involved too many steps (Supplementary Tables 1 and 2 summarise

224 the survey responses). In response, we have subsequently developed new chemistries to reduce

225 assay time to 3.5 hours by replacing the 1.5-hour blood DNA preparation by a 30-minute plasma RNA extraction and the 2-hour PCR by 1-hour RT-PCR.

Our study shows it is feasible to use Aquarium to train local laboratory personnel with basic experience in lab work and onboard an HIVDR test, but this pilot study was limited to the use of contrived specimens to establish analytical performance. Due to limited resources and allocated study time, each participating laboratory technician was able to perform the OLA-Simple kit once.

232 Thus, we were not able to assess the ability of each technician to maintain or improve their skills.

233 A larger demonstration and evaluation study that includes processing HIV-infected clinical 234 specimens on multiple OLA-Simple runs is ongoing in Kenya to assess the robustness of our HIVDR test. 
medRxiv preprint doi: https://doi.org/10.1101/2021.05.06.21256654; this version posted May 8, 2021. The copyright holder for this preprint (which was not certified by peer review) is the author/funder, who has granted medRxiv a license to display the preprint in perpetuity. It is made available under a CC-BY-NC-ND 4.0 International license .

237 The Aquarium software has useful features for HIVDR testing such as automatic collection of 238 operator interactions in Aquarium's virtual laboratory notebook that can be useful for 239 troubleshooting. Each kit item is labeled with a unique identifier that Aquarium instructions use in 240 conjunction with corresponding pictures to avoid ambiguity and reduce the extent of in-person 241 training needed. Uniquely labeled items also allow tracking of stock consumption in real-time

242 which can be useful and timesaving for laboratory management. Importantly, Aquarium could link 243 test results to treatment algorithms to advise clinicians, and algorithms could be changed as clinical 244 recommendations or policies change.

\section{Conclusion}

247 Aquarium-based software enabled deployment of the OLA-Simple with minimal training by 248 lowering technical skills required to perform such test. Local laboratory technicians operated the 249 OLA-Simple for the first-time with good recovery in sample preparation and high accuracy of 250 HIVDR detection. Human-in-the-loop automation could facilitate daily operations of laboratory251 based assays and increase the accuracy and assay performance in small laboratories.

\section{Competing interests}

254 The authors have no conflicts of interest to declare

\section{Authors' contributions}

257 NP, RK, and YY conceived the vision for Aquarium for OLA-Simple. NP, NH, DK, RK, IB, and 258 JL developed and prepared the OLA-Simple kits. JDV, YY, and EK developed the software 259 application for this work. JDV and IB travelled to Kenya to conduct this study. IB, NP, PR, and 260 JDV analysed the data. BRL, LMF, EK oversaw the overall study on the Seattle side. SRS, BC 261 and MHC oversaw the study design on the Kenya side and helped enrolled local technicians in 262 Kenya. All authors contributed to writing of this manuscript and approved the final version for 263 submission.

\section{Acknowledgments}

266 We are grateful to the Coptic Hospital and the Coptic Hope Center for their support and to the technologists from these institutions who participated in this study. We thank Syamal 
medRxiv preprint doi: https://doi.org/10.1101/2021.05.06.21256654; this version posted May 8, 2021. The copyright holder for this preprint (which was not certified by peer review) is the author/funder, who has granted medRxiv a license to display the preprint in perpetuity. It is made available under a CC-BY-NC-ND 4.0 International license .

Raychauduri, Dindo Reyes, Kim Polizzi, and Jessica Price at InBios International, Inc. for producing the lateral flow strips used in the validation study; and Aarthy Vallur and Kathryn Hjerrild of InBios International, Inc. for providing feedback on OLA-Simple prototypes. Funding: This work was supported by R01 AI110375 (LMF); R01 AI145486-01A1 (BRL); T32

272 HD007233 (RK); and UW Bioengineering Pilcher Faculty Fellowship (BRL). The content of 273 this work is not influenced by funders.

\section{References}

276 [1] Sarkozi L, Simson E, Ramanathan L. The effects of total laboratory automation on the management of a clinical chemistry laboratory. Retrospective analysis of 36 years. Clin Chim Acta. 2003;329(1-2):89-94.

279 [2] Holland LL, Smith LL, Blick KE. Total laboratory automation can help eliminate the 280 laboratory as a factor in emergency department length of stay. Am J Clin Pathol.

$281 \quad 2006 ; 125(5): 765-70$.

282 [3] Da Rin G, Zoppelletto M, Lippi G. Integration of Diagnostic Microbiology in a Model of 283 Total Laboratory Automation. Lab Med. 2016;47(1):73-82.

284 [4] Miler M, Nikolac Gabaj N, Dukic L, Simundic AM. Key Performance Indicators to 285 Measure Improvement After Implementation of Total Laboratory Automation Abbott 286 Accelerator a3600. J Med Syst. 2017;42(2):28.

287 [5] Chung HJ, Song YK, Hwang SH, Lee DH, Sugiura T. Experimental fusion of different 288 versions of the total laboratory automation system and improvement of laboratory turnaround 289 time. J Clin Lab Anal. 2018;32(5):e22400.

290 [6] Bolduc S. Sputum collection and transport in Africa: perspectives from Mozambique 291 part 1: Challenges DNA Genotek's Infectious Disease Blog. 2016.

292 [7] UNAIDS. Global HIV \& AIDS statistics - 2020 fact sheet. 2020.

293 [8] Kulkarni S, Jadhav S, Khopkar P, Sane S, Londhe R, Chimanpure V, et al. GeneXpert 294 HIV-1 quant assay, a new tool for scale up of viral load monitoring in the success of ART 295 programme in India. BMC Infect Dis. 2017;17(1):506.

296 [9] Manoto SL, Lugongolo M, Govender U, Mthunzi-Kufa P. Point of Care Diagnostics for 297 HIV in Resource Limited Settings: An Overview. Medicina (Kaunas). 2018;54(1). 
medRxiv preprint doi: https://doi.org/10.1101/2021.05.06.21256654; this version posted May 8, 2021. The copyright holder for this preprint (which was not certified by peer review) is the author/funder, who has granted medRxiv a license to display the preprint in perpetuity. It is made available under a CC-BY-NC-ND 4.0 International license . Sentosa ${ }^{\circledR}$ SQ HIV-1 Genotyping Assay and Associated Sentosa ${ }^{\circledR}$ NGS (Next Generation Sequencing) Workflow System. 2020.

301 [11] May S, Adamska E, Tang J. Evaluation of Vela Diagnostics HIV-1 genotyping assay on 302 an automated next generation sequencing platform. J Clin Virol. 2020;127:104376.

303 [12] Raymond S, Nicot F, Abravanel F, Minier L, Carcenac R, Lefebvre C, et al. Performance 304 evaluation of the Vela Dx Sentosa next-generation sequencing system for HIV-1 DNA genotypic 305 resistance. J Clin Virol. 2020;122:104229.

306 [13] Dessilly G, Goeminne L, Vandenbroucke AT, Dufrasne FE, Martin A, Kabamba-Mukadi 307 B. First evaluation of the Next-Generation Sequencing platform for the detection of HIV-1 drug 308 resistance mutations in Belgium. PLoS One. 2018;13(12):e0209561.

309 [14] Kingwara L, Karanja M, Ngugi C, Kangogo G, Bera K, Kimani M, et al. From Sequence 310 Data to Patient Result: A Solution for HIV Drug Resistance Genotyping With Exatype, End to 311 End Software for Pol-HIV-1 Sanger Based Sequence Analysis and Patient HIV Drug Resistance 312 Result Generation. J Int Assoc Provid AIDS Care. 2020;19:2325958220962687.

313 [15] Duarte HA, Beck IA, Levine M, Kiptinness C, Kingoo JM, Chohan B, et al.

314 Implementation of a point mutation assay for HIV drug resistance testing in Kenya. AIDS. 315 2018;32(16):2301-8.

316 [16] Panpradist N, Beck IA, Ruth PS, Avila-Rios S, Garcia-Morales C, Soto-Nava M, et al.

317 Near point-of-care, point-mutation test to detect drug resistance in HIV-1: a validation study in a 318 Mexican cohort. AIDS. 2020.

319 [17] Panpradist N, Beck IA, Chung MH, Kiarie JN, Frenkel LM, Lutz BR. Simplified Paper 320 Format for Detecting HIV Drug Resistance in Clinical Specimens by Oligonucleotide Ligation. $321 \quad$ PLoS One. 2016;11(1):e0145962.

322 [18] Panpradist N, Beck IA, Vrana J, Higa N, McIntyre D, Ruth PS, et al. OLA-Simple: A 323 software-guided HIV-1 drug resistance test for low-resource laboratories. EBioMedicine. 324 2019;50:34-44.

325 [19] Keller B, Vrana J, Miller A, Newman G, Klavins E. Aquarium: The Laboratory 326 Operating System (Version v2.5.0). Zenodo http://doiorg/105281/zenodo2535715. 2019. 
medRxiv preprint doi: https://doi.org/10.1101/2021.05.06.21256654; this version posted May 8, 2021. The copyright holder for this preprint (which was not certified by peer review) is the author/funder, who has granted medRxiv a license to display the preprint in perpetuity.

It is made available under a CC-BY-NC-ND 4.0 International license .

327 [20] Chung MH, Drake AL, Richardson BA, Reddy A, Thiga J, Sakr SR, et al. Impact of prior 328 HAART use on clinical outcomes in a large Kenyan HIV treatment program. Curr HIV Res.

$3292009 ; 7(4): 441-6$.

330 [21] Vrana J. OLA Simple HIV Drug Resistance Test: An Aquarium Workflow

331 Github.com2020 Available from: klavinslab.github.io/ola-simple/.

332 [22] Panpradist N, Beck IA, Vrana J, Higa N, McIntyre D, Ruth PS, et al. OLA-Simple: a

333 software-guided HIV-1 drug resistance test for low-resource laboratories. EBiomedicine. 2019;In

334 press.

335 [23] Zunt JR, Montano SM, Beck I, Alarcon JO, Frenkel LM, Bautista CT, et al. Human T-

336 lymphotropic virus type 1-associated myelopathy/tropical spastic paraparesis: viral load and

337 muscle tone are correlated. J Neurovirol. 2006;12(6):466-71.

338 [24] Panpradist N, Wang Q, Ruth PS, Kotnik JH, Oreskovic AK, Miller A, et al. Simpler and

339 faster Covid-19 testing: Strategies to streamline SARS-CoV-2 molecular assays. EBioMedicine.

$340 \quad 2021 ; 64: 103236$.

341 [25] Lessells RJ, Avalos A, de Oliveira T. Implementing HIV-1 genotypic resistance testing in

342 antiretroviral therapy programs in Africa: needs, opportunities, and challenges. AIDS Rev.

$343 \quad 2013 ; 15(4): 221-9$. 